\title{
On a Train to Altona
}

\section{Michael Crane}

All the socialites in Toorak and Brighton

are buying gowns for the Charity Ball

and their Range Rovers are being serviced, the catering paid for in advance,

while I'm on a train to Altona

as it winds past the oil refineries

far away from the Town Hall ballroom.

All the artists at the fair

held in the Exhibition Centre trade room

exchange business cards and resumes

preparing to ambush an agent,

while I'm on a train to Altona

and the Westgate bridge in the distance

carries the burden of drivers on its shoulders.

All the business men and fancy dancers argue who will pay the restaurant bill refusing to tip the waiter and scowl at the chef and a million mobile phones receive text messages, while I'm on a train to Altona where impoverished choirs rehearse in rundown warehouses by the beach.

It's a train to Altona carrying me far away from the arguments of the city, away from bickering women and demanding men. Maybe the beautiful people don't live there but the children don't seem to mind singing nursery rhymes in kindergarten as the flame from the oil refinery reaches the sky. 